\title{
Analytic Hierarchy Process applied to the selection of knowledge management approach in technology-based companies
}

\author{
Sandra Miranda Neves ${ }^{a}$, Carlos Eduardo Sanches da Silva ${ }^{a}$, Aneirson Francisco da Silva ${ }^{b}$, \\ Cristiana Rennó D'Oliveira ${ }^{c}$, Bárbara Elizabeth Pereira Sotomonte ${ }^{a}$ \\ oFederal University of Itajubá \\ bSão Paulo State University \\ 'Federal University of São Carlos \\ e-mails: sanmirneves@hotmail.com; sanches@unifei.edu.br; aneirson@yahoo.com.br; cristiana@dep.ufscar.br; ad_barbara@yahoo.com.br
}

\begin{abstract}
Within the fields of knowledge management and risk management of projects, the transformation of the existing knowledge in the organization into competitive advantage was proposed in order to make the decisionmaking process possible. The main purpose of this article was to select an approach to knowledge management that gathered the applicable criteria to the decision-making and risk management of projects in technology-based companies. It was intended to describe, analyze and select the approaches to knowledge management through the use of the Analytic Hierarchy Process (AHP) method. The chosen structured lines of research for the selection of the approach were: Nonaka and Takeuchi's; Davenport and Prusak's; Stewart's; Sveiby's; Terra's and Choo's proposals. The selection was based on the geometric average of the judgments accomplished by six specialists, whose data gathering were collected through direct interview. The adopted method of research was modeling research. The study resulted in the selection of Nonaka and Takeuchi's approach as the most adjusted according to the considered criteria.
\end{abstract}

Keywords: knowledge management, technology-based companies, risk management, AHP.

\section{Introduction}

The technology-based companies are in an environment of competitiveness and risks, in which fast changes occur and the companies must be prepared to absorb. One of the main decisions in this environment is to reduce the time to place a product in the market and the capacity to use the current company knowledge, which will enable the decisions made to result in its competitiveness and survival in the market. Dahlstrand (2007) defines a technology-based company (TBC) as the one that depends on the technology for its growth and survival. It does not usually mean that the technology must be up-to-date or an innovation. New products can be the result of processes of creation, socialization and knowledge storage for all the company. These are accomplished by managers who materialize organizational knowledge throughout projects that involve uncertainties. Cooper (2003) affirms that the knowledge management systems have a strong potential to help risk reduction, due to their gains, excellent information processing and knowledge encapsulation resulting from a great variety of internal and external sources, corroborating with Davenport and Prusak`s concept (1998), that knowledge is the only sustainable source of competitive advantage.
The main goal of this article is to select a knowledge management (KM) approach that refers to the applicable criteria to the decision making and risk management in projects of technology-based companies. It specifically aims at describing and analyzing the approaches of knowledge management and using the Analytic Hierarchy Process (AHP) method to further assist the determination of the adjusted approach to the considered criteria. The prioritization of the main approaches of KM is not intended, ever since they are only complementary, but the assessment whether an author or authors possess a higher interaction with the established criteria in this research is. It is also intended through the analysis to answer the following questioning: Which approach of KM presents greater interaction with the related criteria of decision-making process and risks in $\mathrm{TBC}$ projects?

This research is of applied nature, has exploratory purposes and the approach to the problem is quantitative. The method adopted for this study was the modeling (BERTRAND; FRANSOO, 2002). The article is structured, firstly in the concepts of KM and decision-making process in the selection of the authors and the description of their approaches. Later the contextualization of the aid to decision 
with multiple criteria is presented. Finally, it presents the stages for execution of the AHP method, the results and its conclusions.

\section{Knowledge management and the decision-making process}

There can be found in the literature different definitions for KM (NONAKA; TAKEUCHI, 1995; BOLLINGER; SMITH, 2001; ADAMS; FREEMAN, 2000; ROWLEY, 1999; DAVENPORT; PRUSAK, 1998; SVEIBY, 1997; QUINTAS; LEFRERE; JONES, 1997). In this study, the Nonaka and Takeuchi's concept was considered (1995), according to which $\mathrm{KM}$ is the process to create new knowledge continuously, spreading it in the organization and incorporating it in a quick way to the new products/ services, technologies and systems.

In the organization, the problems present greater complexity and involve a set of uncertainties, requiring the opinion and the participation of a larger number of people, being able to involve some functional levels. Thus, the decision- making process must be well structured, legalized, consistent, clearly treated and disseminated in an adjusted way, so that rumors do not occur. Furthermore, Cooper (2003) claims that, repeatedly, the decision-makers are incapable to act correctly, not due to lack of knowledge, but because they are dependents or misguided by the inexact information that the support systems transmit. It is necessary to make use of data and information that will be transformed into knowledge in order to allow a better decision-making, explicitly, the use of knowledge with wisdom. Regarding the decision-making in projects, the knowledge management can be used to take trustworthy decisions in relation to the strategy, competitors, customers, distribution channels and products and services life cycles (DAVENPORT; PRUSAK, 1998). The employment of KM as the support to the decision-making process consists of a subject of innumerable researches (PADMA; BALASUBRAMANIE, 2009; RANTAPUSKA; IHANAINEN, 2008; NICOLAS, 2004; COURTNEY, 2001; METAXIOTIS et al., 2003; HOLSAPPLE, 2001), hence the capacity to make a good decision is very important for the success of a project (AL-HARBI, 2001). Comprehension and response to the risks in a company is a task that depends on the intellectual capital of the company (NEEF, 2005) and one of the most powerful tools in the risk management in projects is knowledge (COOPER, 2003).

\subsection{Describing and analyzing the approaches of knowledge management}

In order to deal with specified goal, the main authors on $\mathrm{KM}$ accessible in the literature were identified. According to this survey, the selection of these authors was determined and the bibliographical study was accomplished. The scope of the study can be observed as follows.

\subsection{Selection of the main authors}

Serenko and Bontis (2004) accomplished a research on the main publications related to the area of KM and Intellectual Capital (IC) published in three journals: (1) Journal of Intellectual Capital (JIC), (2) Journal of Knowledge Management (JKM), and (3) Knowledge and Process Management (KPM); the objective of the research was the identification of the most cited publications and authors in the KM and IC field of application. The results shown only consisted in the ten more cited, and can be observed in Table 1.

A similar research was accomplished in Brazil by Fell, Rodrigues Filho, and Oliveira (2008), in which 6.096 articles presented in the annals of the ENANPADs (National Meeting of the National Association of the Programs of Post-Graduation in Administration) raised and evaluated the citation frequency on KM in the period of 1997 to 2007. It is observed in Table 2 that, in Brazil, the Terra's Approach was included and was considered the most cited.

The step of selecting the alternatives to compose the AHP was performed in a participative way among the authors of the research and the specialists, in which the four most cited authors in Table 1(Nonaka and Takeuchi, Davenport and Prusak, Stewart and Sveiby) were indicated to compose the alternatives. In addition to these, the most cited Brazilian author was included, available in Table 2 (Terra), and an indication of the author Chun Wei Choo was also incorporated by one of the specialists, though it does not appear in the surveys previously presented, it has a contribution for the research which is related to the decision making process. The validation of the determination occurred with all the specialists. The election for the analysis of the model, and to compose the alternatives of the AHP, can be observed in Table 3 .

The next step of the research consisted of the description and analysis of the KM approach, in accordance with the selected authors.

\subsection{Description and analysis of the $K M$ approach}

A comparative representation of the selected authors was elaborated (NONAKA; TAKEUCHI, 1995; DAVENPORT; PRUSAK, 1998; STEWART, 1997; SVEIBY, 1997; CHOO, 1998; TERRA, 2000), and can be observed in Table 4.

The analysis of the previous table allows to identify that there is a distinction between the authors' content regarding $\mathrm{KM}$, intellectual capital and knowledge organization. Moreover, not all of them contemplate the requirements established in the comparative chart in its publications. After the bibliographical revision and elaboration of the table, the next step of the selection to the KM approach was the 
Table 1. The most cited authors in KM and IC - up to 2003.

\begin{tabular}{|c|c|c|c|c|}
\hline Classification & Book & Authors & Publication & Frequency \\
\hline 1 & The knowledge creating company & Nonaka, I. and Takeuchi, H. & 1995 & 122 \\
\hline 2 & Working knowledge & Davenport, T. H. and Prusak, L. & 1998 & 58 \\
\hline 3 & Intellectual capital & Stewart, T. A. & 1997 & 55 \\
\hline 4 & The new organizational wealth & Sveiby, K. E. & 1997 & 50 \\
\hline 5 & A dynamic theory of organizational knowledge... & Nonaka, I. & 1994 & 46 \\
\hline 6 & The knowledge creating company & Nonaka, I. & 1991 & 44 \\
\hline 7 & The fifth discipline & Senge, $\mathrm{P}$. & 1990 & 42 \\
\hline 8 & Intellectual capital & Edvinsson, L. and Malone, M. S. & 1997 & 40 \\
\hline 9 & Reengineering the corporation & Hammer, M. and Champy, J. & 1993 & 39 \\
\hline 10 & The tacit dimension & Polanyi, M. & 1966 & 32 \\
\hline
\end{tabular}

Source: Adapted from Serenko and Bontis (2004).

Table 2. Most cited authors in KM studies - ENANPAD's from 1997 to 2007.

\begin{tabular}{|l|c|}
\hline \multicolumn{1}{|c|}{ Authors } & Frequency \\
\hline Nonaka, I. and Takeuchi, H. & 53 \\
\hline Davenport, T. & 46 \\
\hline Prusak, L. & 32 \\
\hline Senge, P. & 30 \\
\hline Stewart, T. & 28 \\
\hline Sveiby, K. & 27 \\
\hline Terra, J. C. C. & 27 \\
\hline Yin, R. & 22 \\
\hline Garvin, D. & 18 \\
\hline Prahalad, C. K. and Hamel, G. & 18 \\
\hline Drucker, P. & 17 \\
\hline Leonard-Barton, D. & 14 \\
\hline
\end{tabular}

Source: Adapted Fell, Rodrigues Filho and Oliveira (2008).

Table 3. Selected Authors for Analysis and Composition of the Alternatives of AHP.

\begin{tabular}{|c|}
\hline Selected Author to comprehend the alternatives of AHP \\
\hline Nonaka, I. and Takeuchi, H. \\
\hline Davenport, T. and Prusak, L. \\
\hline Stewart, T. \\
\hline Sveiby, K. \\
\hline Terra, J. C. \\
\hline Choo, C. W. \\
\hline
\end{tabular}

application of the MCDM (Multiple Criteria of DecisionMaking) using AHP method developed by Saaty in the 70's.

\section{Tool to the multiple criteria decision-making}

According to Saaty (1990), the use of the AHP for the decision-making is a theory of relative measure, based in comparison between pairs, to get tables of normalized absolute numbers which elements are used as priorities afterwards. Matrices of comparison between pairs are formed providing judgments, esteeming the dominance using absolute numbers in a scale from 1 to 9 (SAATY;
SHANG, 2007). As the AHP is a multi-criteria process, it is necessary to combine the priorities of the alternatives derived from the different scopes (SAATY, 2006).

Although there are in the literature potential limitations of disapproval related to the AHP techniques (DYER, 1990; BARZILAI, 1998; BELTON; GEAR, 1983), it has been used successfully in a variety of areas and for different purposes, such as: decision-making in what it refers to the allocation of resources, forecasts, associated use of the approaches as well as the Total Quality Management (TQM), reengineering processes in the businesses, Quality Function Deployment (QFD) and Balanced Scorecard (FORMAN; GASS, 2001). For evaluating and ranking potential suppliers (LEVARY, 2008), selecting the best machine (CHANG et al., 2007) and transportation fuels (POH; ANG, 1999). Revisions on its applications throughout the years can be seen in Ho (2008), Liberatore and Nydick (2008) and in Vaidya and Kumar (2006), whose studies also cite the use of the AHP jointly with mathematical programming and other multicriteria tools such as Fuzzy Theory and Multi-Attribute Utility Theory (MAUT). Drake (1998) presents the benefits offered for the application of the AHP in the education of engineering. Based on that information it was adopted the use of the AHP in the present research. Figure 1 presents an example of hierarchy for a problem of three levels.

The AHP method provides a structured framework for setting priorities on each level of the hierarchy using pairwise comparisons that are quantified using 1-9 scales, according to Saaty (1977) as presented in Table 5 and Equation 1.

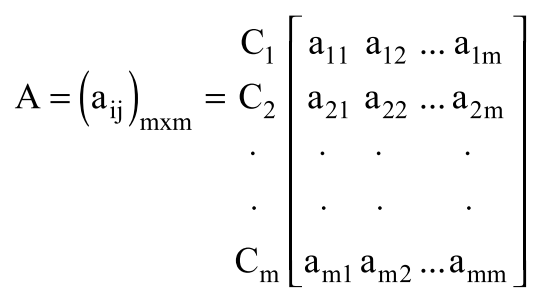


Table 4. Comparative chart of the knowledge management approaches.

\begin{tabular}{|c|c|c|}
\hline Definition & Approach/Creation/Generation & Conversion/Codification/Transmission \\
\hline \multicolumn{3}{|c|}{ Nonaka and Takeuchi (1995) } \\
\hline $\begin{array}{l}\text { KM defined as the process to create new } \\
\text { knowledge continuously spreading it in the } \\
\text { organization and incorporating it in a quick } \\
\text { way to the new products/services, technologies } \\
\text { and systems, perpetuating the change inside the } \\
\text { organization. }\end{array}$ & $\begin{array}{l}\text { Knowledge spiral: ontological and } \\
\text { epistemological dimension. } \\
\text { Conditions that promote the organizational } \\
\text { knowledge creation: organization purpose, } \\
\text { autonomy, fluctuation, creative chaos, redundancy } \\
\text { and variety requisite. } \\
\text { Knowledge creation process steps: (1) Tacit } \\
\text { knowledge sharing; (2) Concepts creation; } \\
\text { (3) Concepts justification; (4) Archetype } \\
\text { construction - that may be prototype; } \\
\text { (5) Knowledge leveling. }\end{array}$ & $\begin{array}{l}\text { Conversion and codification: } \\
\text { 1) Socialization: physical and mental experience. } \\
\text { 2) Externalization: metaphor, analogy. } \\
\text { 3 Combination: Systematization of concepts. } \\
\text { 4) Internalization: to learn by doing. } \\
\text { Sharing: metaphors and analogies, redundancy, } \\
\text { experience, creation of archetypes of products, } \\
\text { multidisciplinary teams and so on. }\end{array}$ \\
\hline
\end{tabular}

\section{Stewart (1997)}

Intellectual Capital is intellectual matter: knowledge, Organizations based on the creation of the The necessary tacit knowledge if it is to become information, experience, intellectual property, organizational knowledge make intensive use of explicit; what was not said needs to be spoken out experience - that can be used to create wealth.

the knowledge, substituting its traditional supplies loud. On the other hand, it can not be examined, be by means of information, assuming three forms: improved or be shared.

Human Capital (HC), Capital of the Customer (CC)

and Structural Capital (SC).

\section{Davenport and Prusak (1998)}

The KM is composed by a set of processes that searches the knowledge creation, its registration and transfer altogether with environmental support.
Separation between data, information and Codification and coordination of the knowledge: to knowledge. Transformation of the information make use of the organizational knowledge in a way in knowledge: it is possible through comparison, that it becomes accessible for the one needing it. consequences, connection and conversation. Transference of knowledge $=$ transmission + Generation of knowledge inside the companies: absorption (and use).

acquisition, devotion of resources, fusing, adaptation Knowledge market : it recognizes the interest that and networks (net). The knowledge is inefficacious, the individuals have while holding the knowledge if it will not be used. they possess, and to share what they need to receive in exchange.

\section{Sveiby (1997)}

KM can be understood as the art of value creation by the efficient use of the intangible assets of an organization.
Levels of perception of the process of knowledge management:

Individual perspective: it includes the motivations and the capacities of the individuals;

Organizational perspective: it includes the resources Information: indirect by means of vehicles (lectures, and the essential abilities of the organizations. Its proposal is called "monitor of intangible asset" supported in 3 anchor areas: growth and renewal, efficiency and stability.

The model of evaluation of intangible: a) employees competences; b) structure; c) external structure.

\section{Terra (2000)}

It claims that the people are the only agents of change and the other assets are resulted from the human action.

Transmission:

training, etc). Tradition: direct, person the person, experience, communication.

.

$\mathrm{KM}$ is an effort to make the knowledge of an organization available to those who need it, when it is necessary, where it is necessary, and how it is expected to be necessary, aiming to enhance the human and organizational performance.

It specifies seven dimensions through managerial practice from which the KM can be understood: dimension 1) strategic factors and the role of high administration; dimension 2) organizational culture and values; dimension; 3) organizational structure; dimension; 4) administration of human resources; dimension; 5) information systems; dimension; 6) measuring results; dimension; 7) learning with the environment.

\section{Choo (1998)}

Defines knowledge organization as the one which has information and knowledge that make it well informed and capable of perception and discernment. The processes of information are the basis to create meaning, building knowledge and decision-making. 
Where ai,j represents a quantified judgment on wi/wj with a $i i=1$ and $\mathrm{a}_{\mathrm{ij}}=1 / \mathrm{a} j, i$ for $i, j=1, \ldots \ldots, m$. If the pairwise comparison matrix $\mathrm{A}=(\mathrm{a} i, j) \mathrm{mxm}$ satisfies $\mathrm{aij}=\mathrm{a} i k \cdot \mathrm{a} k j$ for any $i, j, k=1, \ldots, \mathrm{m}$, then $\mathrm{A}$ is said to be perfectly consistent; otherwise it is said to be inconsistent.

Form the pairwise comparison matrix A, the weight vector $\mathrm{W}$ can be determined by solving the following characteristic equation (Equation 2):

$$
\mathrm{AW}=\lambda \max \mathrm{W}
$$

Where $\lambda$ max is the maximum eigenvalue of A. Such a method of determining the weight vector of a pairwise comparison matrix is referred to as the principal right eigenvector method (EM).

Since the Dm may be unable to provide perfectly consistent pairwise comparisons, it is demanded that the pairwise comparison matrix A should have an acceptable consistency, which can be checked by the following consistency ratio (CR), according to Saaty (1990) by the Equation 3.

$$
\mathrm{CR}=\frac{\left(\lambda_{\max }-\mathrm{n}\right) /(\mathrm{n}-1)}{\mathrm{RI}}
$$

Where RI is random inconsistency index, whose value varies with the order of pairwise matrix. Table 6 shows the RI values for the pair wise comparison matrices with the

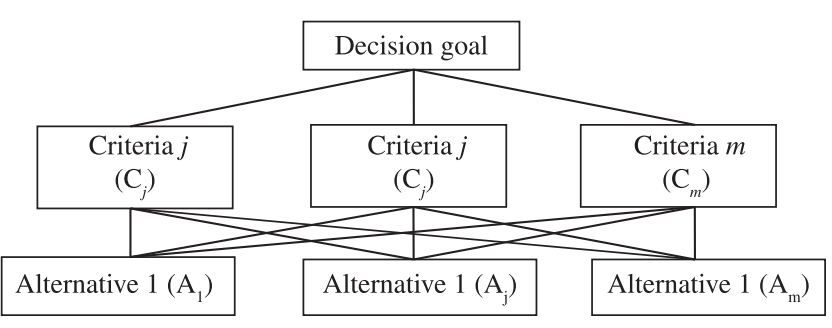

Figure 1. Hierarchy of a typical three-level AHP problem.

Table 5. The 1-9 scales for pairwise comparisons in the AHP.

\begin{tabular}{|c|l|}
\hline Importance intensity & \multicolumn{1}{|c|}{ Definition } \\
\hline 1 & Equal importance \\
\hline 3 & Moderate importance of one over another \\
\hline 5 & Strong importance of one over another \\
\hline 7 & Very strong importance of one over another \\
\hline 9 & Extreme importance of one over another \\
\hline $2,4,6,8$ & Intermediate values \\
\hline Reciprocals & Reciprocals for inverse comparison \\
\hline
\end{tabular}

Table 6. Random inconsistency index for pair wise comparison matrices with the order of 1 to 10 .

\begin{tabular}{|c|c|c|c|c|c|c|c|c|c|c|}
\hline $\mathbf{N}$ & 1 & 2 & 3 & 4 & 5 & 6 & 7 & 8 & 9 & 10 \\
\hline $\mathbf{R I}$ & 0 & 0 & 0.58 & 0.9 & 1.12 & 1.24 & 1.32 & 1.41 & 1.45 & 1.49 \\
\hline
\end{tabular}

order of 1 to 10 (SAATY, 1990). If CR $\leq 0.1$, the pairwise comparison matrix is thought to have an acceptable consistency; otherwise, it needs to be revised (SAATY, 1990).

For the application of the method AHP, the total number of matrix of judgments is given by the Equation 4 .

$$
\mathrm{Q}=\sum_{\mathrm{i}=1}^{\mathrm{n}} \frac{\mathrm{n}_{\mathrm{i}}\left(\mathrm{n}_{\mathrm{i}}-1\right)}{2}
$$

See example follows using AHP for calculus criteria vector (Table 7).

\section{Application of the AHP}

The accomplishment AHP method was based on the stages proposed by Ho, Dey and Higson (2006), as shown in Figure 2.

The software Expert Choice ${ }^{\circledR}$ was used in the research problem, by means of method AHP.

\subsection{Developing hierarchy of problem}

The model with objective, criteria, sub criteria and alternatives, was elaborated according to Figure 3.

\subsection{Accomplishment of the judgments}

Provided the domain in the approached topics, six specialists for the accomplishment of the judgments were selected (Table 8).

The chosen specialists also research technology based incubators with national reference. The number of judgments to be accomplished defined by Equation 4, were: 3 criteria generating 3 judgments and 6 alternatives generating 15 judgments for each criterion, which totals 48 judgments for each specialist or 288 judgments in the total.

There are three ways of combining the individual judgments in order to form a sentence for the group: According to Saaty and Shang (2007), the first one is the voting consensus, when the decision making happens in a group and it is necessary to add the preferences of the individuals in a classification consensus, which requires that the group should make in agreement with each entrance of the judgment matrix, which is difficult to reach. The second technique consists in each integrant of the group to firstly accomplish the judgment and secondly to group them by means of the geometric average. According Saaty (2003), the third one occurs when the judgments between the individuals that compose a definitive group are dispersed; being necessary to group the judgments by means of an eigenvector. Regarding this study, the consensus was adopted by means of the geometric average of the judgments of the criteria and the alternatives. The relative importance between the criteria was established using the fundamental 
Table 7. Example using AHP for calculus criteria vector.

\begin{tabular}{|c|c|c|c|c|c|}
\hline Criteria & $\mathrm{C}_{1}$ & $\mathbf{C}_{2}$ & $\mathrm{C}_{3}$ & Eigenvector & Criteria of vector $(W)$ \\
\hline $\mathrm{C}_{1}$ & 1 & $a_{12}$ & $a_{13}$ & \multirow{3}{*}{$V_{i}=\prod_{i=1}^{n} a_{i j}{ }^{\frac{1}{n}}$} & $\mathrm{~W}_{\mathrm{i}}=\mathrm{V}_{\mathrm{i}} / \sum \mathrm{V}_{\mathrm{i}}$ \\
\hline $\mathrm{C}_{2}$ & $1 / a_{12}$ & 1 & $a_{23}$ & & $\mathrm{~W}_{\mathrm{i}}=\mathrm{V}_{\mathrm{i}} / \sum \mathrm{V}_{\mathrm{i}}$ \\
\hline $\mathrm{C}_{3}$ & $1 / a_{13}$ & $1 / a_{23}$ & 1 & & $\mathrm{~W}_{\mathrm{i}}=\mathrm{V}_{\mathrm{i}} / \sum \mathrm{V}_{\mathrm{i}}$ \\
\hline Eigenvalue $\lambda_{\max }$ & & $\mathrm{C}_{\mathrm{ij}} \times$ & & $\sum \mathrm{V}_{\mathrm{i}}$ & $\sum \mathrm{W}_{\mathrm{i}}=1$ \\
\hline Consistency ratio (CR) & \multicolumn{5}{|c|}{$\underline{\left(\lambda_{\max }-n\right) /(n-1)}$} \\
\hline
\end{tabular}

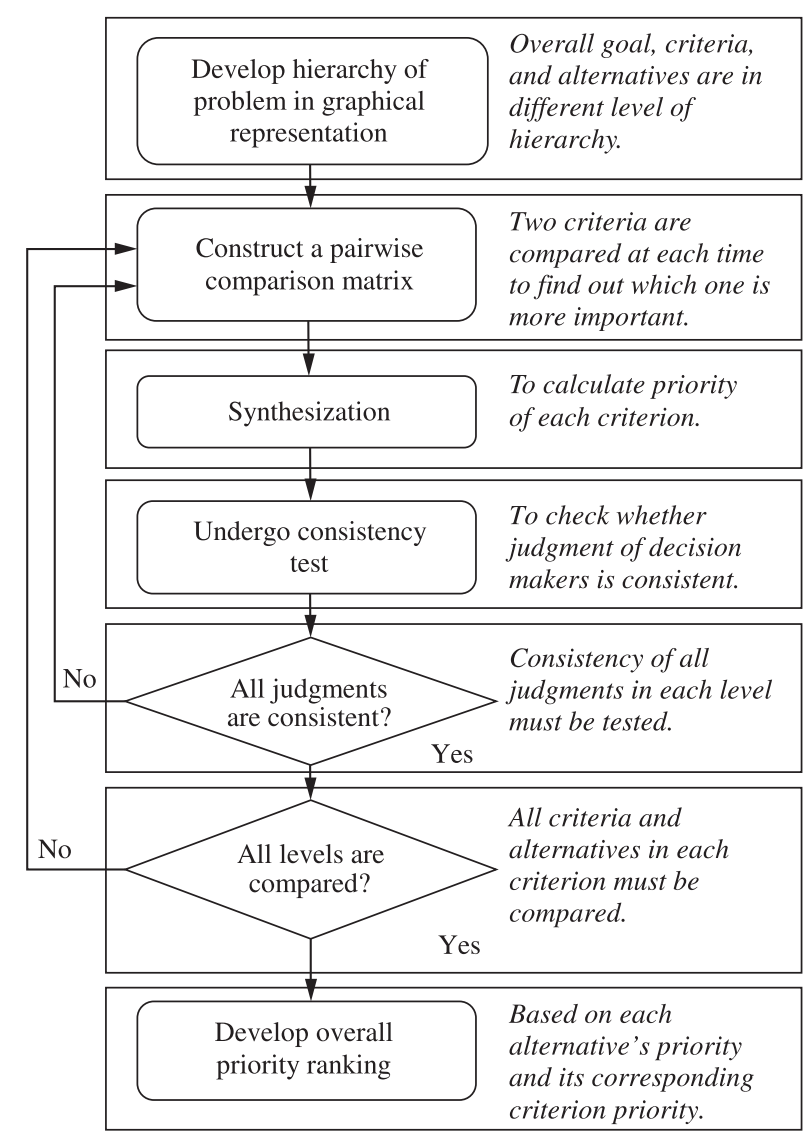

Figure 2. The flowchart of the analytic hierarchy process. Source: Adapted by Ho, Dey and Higson (2006).

scale (SAATY, 1977). Table 9 shows the results of the grouped judgments of the criteria.

For the matrix of judgments of the criteria (Table 9) the judgments had a CR of 0.00 , presenting consistency. Table 10 presents the matrix of judgment of the alternatives (grouped), that is, a composed matrix for the values of performance of the alternatives for each criterion. The CR of the matrix of judgment of the alternatives in relation to the criteria of Decision Making Process, TBC and
Project Management/Risks had presented a CR lower than 0.1 , presenting consistency. It is observed that TBC is the criterion that received greater weight and, therefore, presented greater importance to reach the objective established in this research, followed by Decision Making Process and Project Management/Risks.

Multiplying the judgment of the alternatives (Table 10) by the vector of importance of the criteria (Table 9), the vector of decision or the vector of global performance is determined, in the synthesis of the results using the Table 11.

\subsection{Developing overall priority ranking and analysis of sensitivity}

It can be observed, through the analysis of Table 11, that the approach which presents superior weight in relation to the established criteria is Nonaka and Takeuchi's Approach (0.268), followed by Davenport and Prusak's Approach (0.231).

After that, the global analysis of the weights of the criteria in relation to the objective and the performance of the alternatives regarding the criteria was accomplished, considering the criteria of Decision Making Process (C1), TBC (C2) and Project Management/Risks (C3), as can be observed by means of Figure 4.

The weight of the criteria regarding the alternatives presented in the TBC $(\mathrm{C} 2)$ criterion attended 0.366 of the objective, afterwards, Decision-Making Process with 0.352 (C1) and Project Management/Risks with 0.282 (C3). Regarding the considered objective, the criterion of superior weight was TBC (C2). Analyzing the alternatives in relation to the criteria, for the criterion of Decision Making Process (C1) and TBC (C2) alternative Nonaka and Takeuchi presented greater participation in relation to the others, for the criterion of Management of Projects/ Risks (C3). Davenport and Prusak, on the other hand, got better weight. The application of the method AHP indicates that the selection of the approach of Nonaka and Takeuchi (alternative of higher value of decision vector) as the one that better fits the established criteria. 


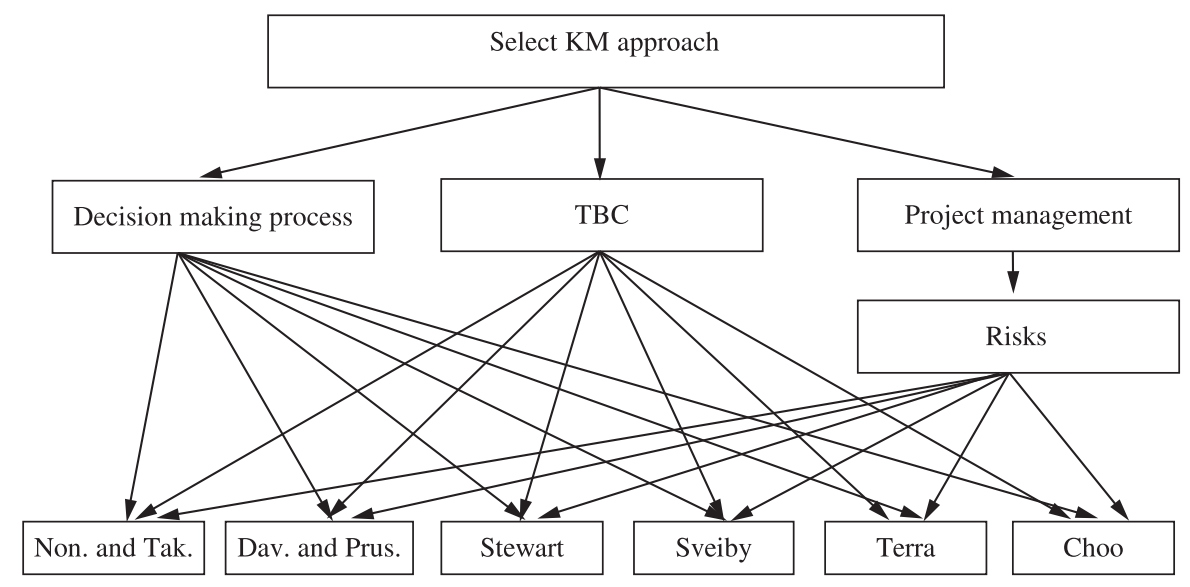

Figure 3. Hierarchy of problem.

Table 8. Description of the specialists for the judgment of the AHP.

\begin{tabular}{|c|l|l|}
\hline Number & \multicolumn{1}{|c|}{ Specialists } & \multicolumn{1}{c|}{ Description } \\
\hline 2 & $\begin{array}{l}\text { Researchers of UNIFEI } \\
\text { Federal University of Itajubá } \\
- \text { Brazil) }\end{array}$ & $\begin{array}{l}\text { 1 Professor (Project management and development of products), with PHD in the field of } \\
\text { Risk Management. Responsible for the nucleus of products development of an institute of } \\
\text { incubated technology-based companies. Researcher of NEMATI (Nucleus of Excellence in } \\
\text { Manufacturing and Innovation Technology). } \\
1 \text { Professor (Business Administration) with Master's Degree in the Management Area, } \\
\text { whose Doctor's Degree in the subject is related to knowledge management. Experience in } \\
\text { development of project management software of incubated companies. }\end{array}$ \\
\hline 2 & $\begin{array}{l}\text { Researchers of UFSCAR } \\
\text { Federal University of São } \\
\text { Carlos - Brazil) }\end{array}$ & $\begin{array}{l}\text { 1 Researcher of GEPEQ, professor (Business Administration), with Master's Degree in the } \\
\text { area of knowledge management, whose Doctor's Degree subject, in development, is related to } \\
\text { performance of quality management systems. } \\
1 \text { Researcher of GEPEQ, with Master's Degree in the area of Product Development and } \\
\text { Knowledge Management. Professional in the quality department of a multinational company. }\end{array}$ \\
\hline \multirow{2}{*}{$\begin{array}{l}\text { Researchers of UFSC } \\
\text { Federal University of Santa }\end{array}$} & $\begin{array}{l}\text { 1 Professor (project methodology, integrated project and conceptual project and products } \\
\text { development management). Participates of the Nucleus of Integrated Development of Products } \\
\text { - NEDIP, which research lines are specialist systems and knowledge engineering. } \\
1 \text { Researcher of the Nucleus of Studies in Innovation, Management and Technology of } \\
\text { Information - IGTI of the Federal University of Santa Catarina since 2005. Doctor's Degree, in } \\
\text { development, related to Engineering and Knowledge Management - since 2006. }\end{array}$ \\
\hline
\end{tabular}

Table 9. Criterion's judgment matrix.

\begin{tabular}{|c|c|c|c|c|}
\hline Criteria & Decision making process & TBC & Project management/risks & Vector of importance \\
\hline $\begin{array}{c}\text { Decision } \\
\text { making process }\end{array}$ & 1 & $1 / \sqrt[6]{1.1247}$ & $\sqrt[6]{3.3335}$ & 0.352 \\
\hline TBC & $\sqrt[6]{1.1247}$ & 1 & $\sqrt[6]{5.3333}$ & 0.366 \\
\hline $\begin{array}{c}\text { Project } \\
\text { management/risks }\end{array}$ & $1 / \sqrt[6]{3.3335}$ & $1 / \sqrt[6]{5.3333}$ & 1 & 0.282 \\
\hline
\end{tabular}

Table 10. Judgment matrix of the alternatives.

\begin{tabular}{|l|c|c|c|}
\hline \multirow{2}{*}{ Alternatives } & \multicolumn{3}{c|}{ Criteria } \\
\cline { 2 - 4 } & Decision making process & TBC & Project management/risks \\
\hline Nonaka and Takeuchi & 0.264 & 0.300 & 0.233 \\
\hline Davenport and Prusak & 0.226 & 0.189 & 0.288 \\
\hline Stewart & 0.170 & 0.177 & 0.137 \\
\hline Sveiby & 0.145 & 0.154 & 0.138 \\
\hline Terra & 0.064 & 0.079 & 0.060 \\
\hline Choo & 0.131 & 0.101 & 0.144 \\
\hline CR & 0.04 & 0.02 & 0.03 \\
\hline
\end{tabular}


Table 11. Decision vector.

\begin{tabular}{|l|c|}
\hline \multicolumn{1}{|c|}{ Alternatives } & Decision vector \\
\hline Nonaka and Takeuchi & 0.268 \\
\hline Davenport and Prusak & 0.231 \\
\hline Stewart & 0.163 \\
\hline Sveiby & 0.146 \\
\hline Choo & 0.124 \\
\hline Terra & 0.068 \\
\hline CR & 0.02 \\
\hline
\end{tabular}

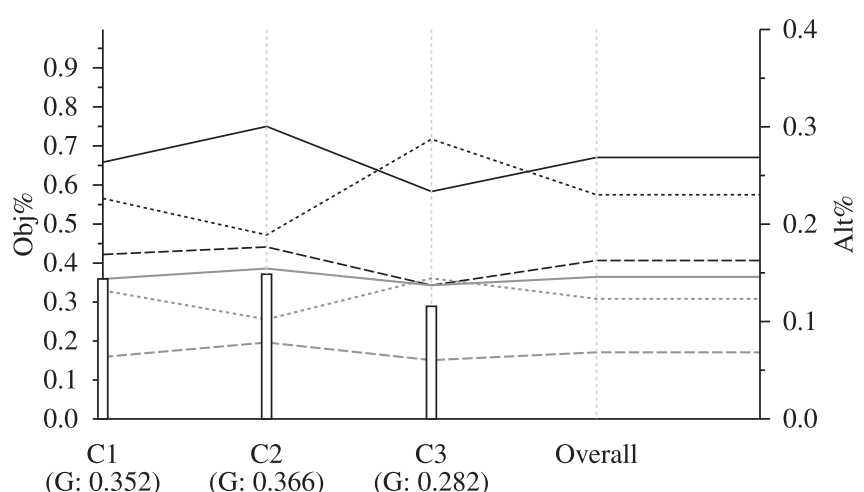

\begin{tabular}{|lll|}
\hline Nonaka & -...... Devenport & ---- Stewart \\
Sveiby & …-... Choo & ---- Terra \\
\hline
\end{tabular}

Figure 4. Global analysis.

The final priorities are very dependent on the criteria weights. The sensitivity analysis aims at evaluating the limit that permits flexibilizing the weight of one definite criterion, making the occurrence of inversion of the alternatives possible. This evaluation can be determined through panoramas proposals that supply information concerning the stability of the result. If the result is sensible to the small changes in the judgments it should be reevaluated. For the criterion of Decision Making Process (C1), according to the greater weight $(0.352)$, the alternative of greater participation is Nonaka and Takeuchi, once any other weight associated to this criterion could not intervene with the result (Figure 5).

For the criterion of TBC $(\mathrm{C} 2)$, it presented the greatest weight (0.366) and was identified that, if it was reduced to approximately 0.22, Davenport and Prusak's Alternative would be the dominant one (Figure 6).

For the criterion of Management of Projects/Risks (C3), with weight 0.282 , it was identified that if the Nonaka and Takeuchi's Alternative had raised to approximately 0.58 , it would have been the dominant one. It was verified then, the importance of the analysis of sensitivity for a better understanding of the variables that compose the decision model.

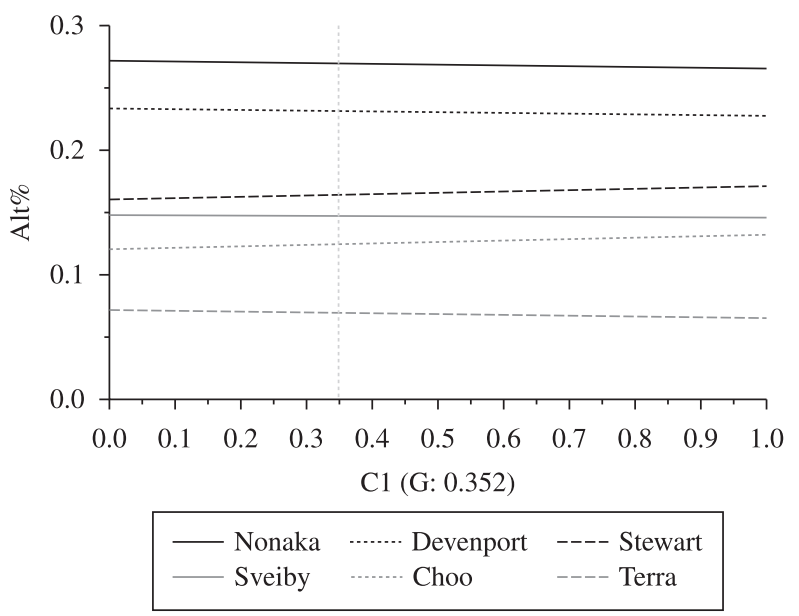

Figure 5. Analysis of sensitivity of the decision-making process criterion.

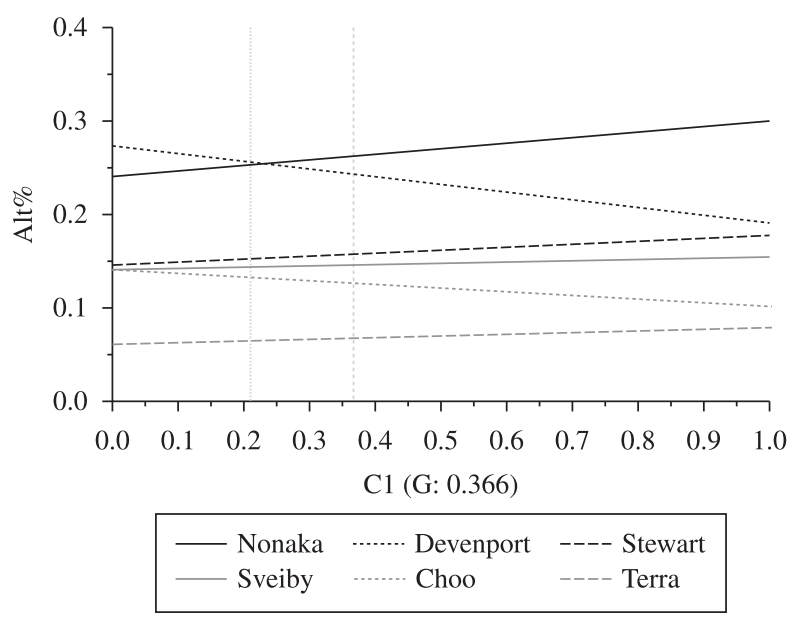

Figure 6. Analysis of the sensitivity criterion TBC.

\section{Discussions and conclusions}

The KM approaches present similarities and contributions. However, its application in specific contexts, such as project management, Decision-Making Process and technologybased companies, lead to the selection of the approaches. The comparative description of the KM approaches, accomplished in the theoretical enrichment, led to the selection of the Choo approach proposal as being the most adjusted. However, in the context of this research, it was one of the approaches that were less indicated. It was perceived that the Nonaka and Takeuchi's Approach was selected due to the fact that they based their theory on innovations (new products/services, technologies and systems) of the process of product development. The new products are considered as projects for the incubated companies. A factor that corroborates this evaluation is the fact that the criterion TBC has gotten superior weight in the evaluation of the specialists. Davenport and Prusak's was selected as 
the second option, in accordance to the established criteria, probably due to their focus on the generation of knowledge, its registration and its transference in order to support the managerial performance and the management of projects by means of the use of knowledge and its techniques, and attributable to cite: learned lessons, repositories of the knowledge, practical communities among others.

Another important point worth noting is that the approach selected in this research was considered for the use in incubated TBC's, and will be applied in the conduction of a case study, and provided that its enclosure in other companies will have to be analyzed. It was perceived that the proper analytical reasoning on the subject in its different perspectives, generated discussions that had significantly contributed for the learning, acting as a generating source of knowledge. The method AHP showed to be an adequate and easy handling method, making it possible to enhance the interaction of people with the analyzed problem. For future researches, it is suggested to increase the number of criteria, with the support of these same specialists. Another suggestion would be using analytic network process (ANP), Therefore, this method considers the dependence among the hierarchy structures. Thus, such condition could occur in the considered alternatives in the research, and can later be compared to the results of the ANP with the AHP regarding the compatibility index created by Saaty.

\section{Acknowledgements}

Thanks to FAPEMIG and the CAPES, for the financing that allowed the development of this research, and in special to the interviewees.

\section{References}

ADAMS, E. C.; FREEMAN, C. Communities of practice: bridging technology and knowledge assessment. Journal of Knowledge Management, v. 4, n. 1, p. 38-44, 2000. http://dx.doi.org/10.1108/13673270010315939

AL-HARBI, K. M. AL-S. Application of the AHP in project management. International Journal of Project Management, v. 19, n. 1, p. 19-27, 2001. http://dx.doi. org/10.1016/S0263-7863(99)00038-1

BARZILAI, J. On the decomposition of value functions. Operations Research Letter, v. 22, n. 4-5, p. 159-170, 1998. http://dx.doi.org/10.1016/S0167-6377(98)00015-7

BELTON, V.; GEAR, T. On a Short-coming of Saaty's Method of Analytic Hierarchies. Omega, v. 11, n. 3, p. 228-230, 1983. http://dx.doi.org/10.1016/0305-0483(83)90047-6

BERTRAND, J. W. M.; FRANSOO, J. C. Modeling and simulation: operations management research methodologies using quantitative modeling. International Journal of Operations and Production Management, v. 22, n. 2, p. 241-264, 2002. http://dx.doi. org/10.1108/01443570210414338
BOLLINGER, A. S.; SMITH, R. D. Managing organizational knowledge as a strategic asset. Journal of Knowledge Management, v. 5, n. 1, p. 8-18, 2001. http://dx.doi. org/10.1108/13673270110384365

CHANG, C. W. et al. An application of AHP and sensitivity analysis for selecting the best slicing machine. Computers \& Industrial Engineering, v. 52, n. 2, p. 296-307, 2007. http://dx.doi.org/10.1016/j.cie.2006.11.006

$\mathrm{CHOO}, \mathrm{C}$. W. The Knowing Organization: How organizations use information to construct meaning, create knowledge, and make decisions. New York: Oxford University Press, Inc., 1998.

COOPER, L. P. A research agenda to reduce risk in new product development through knowledge management: a practitioner perspective. Journal of Engineering and Technology Management, v. 20, n. 1-2, p. 117-140, 2003. http://dx.doi.org/10.1016/S0923-4748(03)00007-9

COURTNEY, J. F. Decision making and knowledge management in inquiring organizations: toward a new decision-making paradigm for DSS. Decision Support Systems, v. 31, n. 1, p. 17-38, 2001. http://dx.doi. org/10.1016/S0167-9236(00)00117-2

DAHLSTRAND, A. L. Technology-based entrepreneurship and regional development: the case of Sweden. European Business Review, v. 19, n. 5, p. 373-386, 2007. http://dx.doi. org/10.1108/09555340710818969

DAVENPORT, T. H.; PRUSAK, L. Working Knowledge: How organizations Manage what they know. Harvard Business School Press, 1998.

DRAKE, P. R. Using Analytic Hierarchy Process in Engineering Education. International Journal of Engineering Education, v. 14, n. 3, p. 191-196, 1998.

DYER, J. S. Remarks on the Analytic Hierarchy Process. Management Science, v. 36, n. 3, p. 249-258, 1990. http://dx.doi.org/10.1287/mnsc.36.3.249

FELL, A. F. A.; RODRIGUES FILHO, J.; OLIVEIRA, R. R. A national academic production study about knowledge management through Haberma's knowledge theory. Journal of Information Systems and Technology Management, v. 5, n. 2, p. 251-268, 2008. http://dx.doi.org/10.4301/ S1807-17752008000200004

FORMAN, E. H.; GASS, S. I. The analytic hierarchy process an exposition. Operations Research, v. 49, n. 4, p. 469-486, 2001. http://dx.doi.org/10.1287/opre.49.4.469.11231

HO, W. Integrated analytic hierarchy process and its applications - a literature review. European Journal of Operational Research, v. 186, n. 1, p. 211-228, 2008. http://dx.doi.org/10.1016/j.ejor.2007.01.004

HO, W.; DEY, P. K.; HIGSON, H. E. Multiple criteria decision making techniques in higher education. International 
Journal of Educational Management, v. 20, n. 5, p. 319-337, 2006. http://dx.doi.org/10.1108/09513540610676403

HOLSAPPLE, C. W. Knowledge management support of decision making. Decision Support Systems, v. 31, n. 1, p. 1-3, 2001. http://dx.doi.org/10.1016/S01679236(00)00115-9

LEVARY, R. R. Using the analytic hierarchy process to rank foreign suppliers based on supply risks. Computers \& Industrial Engineering, v. 55, n. 2, p. 535-542, 2008. http://dx.doi.org/10.1016/j.cie.2008.01.010

LIBERATORE, M. J.; NYDICK, R.L. The analytic hierarchy process in medical and health care decision making: a literature review. European Journal of Operational Research, v. 189, n. 1, p. 194-207, 2008. http://dx.doi. org/10.1016/j.ejor.2007.05.001

METAXIOTIS, K. et al. Decision support through knowledge management: the role of the artificial intelligence. Information Management \& Computer Security, v. 11, n. 5, p. 216-221, 2003. http://dx.doi. org/10.1108/09685220310500126

NEEF, D. Managing corporate risk through better knowledge management. The Learning Organization, v. 12, n. 2 , p. 112-124, 2005. http://dx.doi. org/10.1108/09696470510583502

NICOLAS, R.. Knowledge management impacts on decision making process. Journal of Knowledge Management, v. 8, n. 1, p. 20-31, 2004. http://dx.doi. org/10.1108/13673270410523880

NONAKA, I.; TAKEUCHI, H. The knowledge-creating company: how Japanese companies create the dynamics of innovation. New York: Oxford University Press, 1995.

PADMA, T.; BALASUBRAMANIE, P. Knowledge based decision support system to assist work-related risk analysis in musculoskeletal disorder. Knowledge-Based Systems, v. 22 , n. 1, p. 72-78, 2009. http://dx.doi.org/10.1016/j. knosys.2008.07.001

POH, K. L.; ANG B. W. Transportation fuels and policy for Singapore: an AHP planning approach. Computers \& Industrial Engineering, v. 37, n. 3, p. 507-525, 1999. http://dx.doi.org/10.1016/S0360-8352(00)00020-6

QUINTAS, P.; LEFRERE, P.; JONES, G. Knowledge Management: a Strategic Agenda. Long Range Planning, v. 30, n. 3, p. 385-391, 1997. http://dx.doi.org/10.1016/ S0024-6301(97)90252-1
RANTAPUSKA, T.; IHANAINEN, O. Knowledge use in ICT investment decision making of SMEs. Journal of Enterprise Information Management, v. 21, n. 6, p. 585-596, 2008. http://dx.doi.org/10.1108/17410390810911195

ROWLEY, J. What is knowledge management? Library Management, v. 20, n. 8, p. 416-419, 1999. http://dx.doi. org/10.1108/01435129910291175

SAATY, T. L. A scaling method for priorities in hierarchical structures. Journal of Mathematical Psychology, v. 15, n. 3, p. 234-281, 1977. http://dx.doi.org/10.1016/00222496(77)90033-5

SAATY, T. L. Multicriteria Decision Making. The Analytic Hierarchy Process: Planning, Priority Setting, Resource Allocation. 2th ed. Pittsburgh: RWS Publications, 1990.

SAATY, T. L. Decision-making with the AHP: Why is the principal eigenvector necessary. European Journal of Operational Research, v. 145, n. 1, p. 85-91, 2003. http://dx.doi.org/10.1016/S0377-2217(02)00227-8

SAATY, T. L. Rank from comparisons and from ratings in the analytic hierarchy/network processes. European Journal of Operational Research, v. 168, n. 2, p. 557-570, 2006. http://dx.doi.org/10.1016/j.ejor.2004.04.032

SAATY, T. L.; SHANG, J. S. Group decision-making: Headcount versus intensity of preference. Socio-Economic Planning Sciences, v. 41, n. 1, p. 22-37, 2007. http://dx.doi. org/10.1016/j.seps.2005.10.001

SERENKO, A.; BONTIS, N. Meta-Review of Knowledge Management and Intellectual Capital Literature: Citation Impact and Research Productivity Rankings. Knowledge and Process Management, v. 11, n. 3, p. 185-198, 2004. http://dx.doi.org/10.1002/kpm.203

STEWART, T. A. Intellectual Capital: the new wealth of organizations. New York: Published by Doubleday, 1997.

SVEIBY, K. E. The New Organization Wealth: Managing and measuring knowledge-based assests. San Francisco: Berreth-Koehler Publishers, 1997.

TERRA, J. C. C. Gestão do conhecimento: o grande desafio empresarial. São Paulo: Negócio Editora, 2000.

VAIDYA, O. S.; KUMAR, S. Analytic hierarchy process: an overview of applications. European Journal of Operational Research, v. 169, n. 1, p. 1-29, 2006. http://dx.doi.org/10.1016/j.ejor.2004.04.028 